\title{
Artificial Selection Strategies Implementation in a Model for Musical Variation
}

\author{
Implementação de Estratégias de Seleção Artificial \\ em um Modelo para Variação Musical
}

\author{
Carlos de Lemos Almada \\ Universidade Federal do Rio de Janeiro \\ carlosalmada@musica.ufrj.br
}

Abstract: The present paper, integrating a broad research project intended to systematically study musical variation, presents two kinds of strategies employed in population control of derived forms produced in a computational complex. Both strategies are based on the principle of artificial selection, originated from Charles Darwin's Theory of Evolution (Darwin, 1859/1872). Initially commenting on the conception of organic musical creation that provided the theoretical basis for the research and a brief description of four computational programs elaborated for systematical production of variants from a basic musical cell, the study presents the concept of artificial selection and its adaptation to musical context. It is followed by details of the two selection strategies' recent implementation in the system. The paper concludes with a discussion on the results obtained in the current stage of implementation.

Keywords: darwinian artificial selection; organicism; developing variation and Grundgestalt; musical variation; computational music.

Resumo: O presente artigo, que integra um amplo projeto de pesquisa que pretende estudar sistematicamente a variação musical, apresenta dois tipos de estratégias empregadas no controle populacional de formas derivadas em um processo computacional. Ambas as estratégias são baseadas no princípio de seleção artificial, originada da Teoria da Evolução de Charles Darwin (Darwin, 1859/1872). Comentando inicialmente a conceito de criação musical orgânica que aportou a base teórica para a pesquisa e uma breve descrição de quatro programas computacionais elaborados para a produção sistemática de variantes 
de uma célula musical básica, o estudo apresenta o conceito de seleção artificial e sua adaptação para o contexto musical. Prossegue com detalhes de duas estratégias de seleção recentemente implementadas no sistema. $\mathrm{O}$ artigo conclui com a discussão dos resultados obtidos no estado atual da implementação.

Palavras-chave: seleção artificial darwiniana; organicismo; variação progressiva e Grundgestalt; variação musical; música computacional.

\section{1 - Introduction}

This article integrates a broad research project concerned with musical variation. It examines a specific issue of the research, associated to systematical production of a large number of variants from a basic musical unity, which is obtained through the employment of computational tools especially designed for this task. Essentially, the system replicates organic growth, which means the application of transformational operations at a basic musical cell yielding first generation variants, each of them potentially becoming a referential form for the production of a new generation, and so on. It is easy to perceive that this process, if freely performed, will correspond to an exponential curve, resulting in overpopulation of derived forms. ${ }^{1}$ It is also obvious to conclude that this can represent a serious limitation for the system, since it would be quite difficult to manage a very high number of forms, if one considers the usual need of musical/artistic purposes. For the composer/user, the simple choice of the most suitable forms among such a vast pool of alternatives would require more time than the proper compositional work, which is per se a kind of nonsense. A simple solution for this problem was found in evolutionary biology, more precisely in the foundations of Charles Darwin's Natural Selection theory. The next four sections of this study detail the correlations between Darwin's theory and its adaptation and employment in the research, aiming to establish proper means of population control of musical variants. Firstly, the theoretical grounds adopted in the research, on which the construction of the system for variants production is based, are introduced. Secondly, is a concise description of the system and of the four computational modules that integrate it. Thirdly, the concept of artificial selection is examined, as well its adaptation to the needs of the system, resulting in two kinds of strategies. Their implementation is discussed in the last section of this paper, illustrated with some simple musical examples.

\footnotetext{
${ }^{1}$ Considering that there are currently 20 distinct transformational operations registered in the first module of the system (see more details later), for $n$ generations, the number of produced variants can be calculated as $20^{\mathrm{n}}$. Thereby, if one desires to proceed to the $6^{\text {th }}$ generation, for example, the cumulative increase of individuals would be: 1 ( $20^{\circ}$, for generation " 0 ")-20-400-8000160.000-3.200.000-64.000.000 (64 million forms, almost the same as the population of France!).
} 


\section{2 - The organic musical creation}

Sérgio Freitas (2012, p. 65-66) affirms that artificial creation ${ }^{2}$ as emulating the growth of a live being can be traced back to the Classical Greece, uttered in Plato and Aristotle's writings. This line of thought, that was kept alive during the Middle Age (with Saint Augustine, among others) and Renascence, was intensely renewed in the $19^{\text {th }}$ century, becoming one of the main characteristics of the Romanticism. For Leonard Meyer (1989, p. 166ff.) Organicism (as is currently known this aesthetical-philosophical trend) modeled the musical theory and compositional practice during the 1800's, especially among some Austrian and German composers (notably Beethoven and Brahms), being also propelled by scientific thought. Meyer states that this strong influence is due to a change of ideology, from language (that oriented the Enlightenment) to organic growth, which "preeminent manifestation (...) was, of course, the [Darwin's] theory of evolution (...)" (Meyer 1989, p. 166-168). Corroborating this, ideas like "gradual transformation", "progressive growth", "continuous Becoming", "development and openness" and "an increasing preoccupation with the representation of nature" (Meyer 1989, p. 180-190), which are characteristic aspects of the Romantic Zeitgeist, can also be clearly associated to Darwinian principles. These can be summed as endless transformation of beings through variation and selection of the fittest individuals for sexual reproduction, generating an incalculable diversity of species from a common ancestral. ${ }^{3}$

Besides Darwin, one can add another important influence to the musical organic creation in $19^{\text {th }}$ century: Johann Wolfgang von Goethe (1749-1832). Although more known as a philosopher and writer of novels, plays and poems, Goethe was a prolific amateur scientist, whose principal interests were the investigation of the mysteries of colors and life creation. In his book Versuch die Metamorphose der Pflanzen zu erklären, published in 1790, Goethe introduced the concept of Urpflanz (primordial plant), a kind of abstracted model for all the individuals of the same species. He tried, for example, to explain how every apple tree could only produce apples, and not oranges, which represents an interesting first approach to what is now known as the genetic instructions present in the DNA of the cell's nucleus. Essentially, the concept of Urpflanz can be associated to two central, complementary principles of musical creation: coherence (that can also be expressed as unity) and variety. The optimal balance of these two

\footnotetext{
${ }^{2}$ Including, of course, the artistic and, especially, the musical manifestations.

${ }^{3}$ It is important to remark that Darwin conceived these insights without knowing two decisive factors that would confirm his theory only many decades after his death: the occurrence of randomly cellular mutation (the very responsible for genetic variation) and the actual age of Earth (that explained the absence of intermediary vestiges between the innumerable transformations of the species - which was pointed by his contemporary critics as the main flaw of his theory).
} 
parameters - that ultimately produces musical interest - depends on a third concept: economy. By extension, maximal economy can be achieved when all material of a musical piece is obtained through progressive variations from a basic unity, as the blossoming of a complete tree from its seed.

According to Devon Burts (2004, p. 12-15), Goethe's conception influenced Arnold Schoenberg (1874-1951) in the elaboration of the principle of Grundgestalt (approximately, basic format) and, consequently, the correlate idea of developing variation. ${ }^{4}$ Concisely, for Schoenberg, the Grundgestalt of a musical piece corresponds to a short, meaningful fragment (as a motive) that would implicitly contain - in an ideal case, at least - all the possible unfolding of the whole (which would come to the composer's mind in a sort of flash). ${ }^{5}$ It is almost impossible not to compare this concept to a seed, reinforcing its organicist origins. The processes employed to extract from the Grundgestalt the musical material for the piece (and to give it a proper organic structure) correspond to the developing variation techniques, which could also be defined as a kind of series of mutations successively and/or recursively applied to pre-established, derived forms, in a similar manner to what happens with the continuous species transformation proposed by Darwin.

Both Schoenbergian principles are the basis of a research project initiated in 2011, whose essential objective is to produce systematical studies on musical variation, considering both analytical and compositional approaches. ${ }^{6}$ The principal elements of the latter are presented in the next section.

\section{3 - Systematical production of musical variants}

The geneMus Complex (gM) is a group of four sequential and complementary computational modules, designed for systematical production of musical variants from a given Grundgestalt (renamed as the axiom of the system in this specific branch of the research). The complete derivative process in $\mathrm{gM}$ is subdivided into two levels: (1) abstract, in which occurs first order developing variation (DV1) and (2) concrete, associated to second order developing variation (DV2). The former is concerned with the production of variants (labeled as geno-

\footnotetext{
${ }^{4}$ Both principles are described and commented (considering many aspects) by their own creator in several of his books: Schoenberg (1984; 1988; 1990; 1994; 2006). For other sources, presenting multiple perspectives on the subject, see, for instance, Carpenter (1983), Frisch (1984), Dahlhaus (1990), Haimo (1997), Pye (2000), Dudeque (2005) and Colleen (2009).

${ }^{5}$ This conception can be also connected to another Romantic characteristic: the idea of genius and individuality (Meyer 1989, p. 177-179).

${ }^{6}$ For some studies published during the research, see Almada (2011a; 2011b; 2012; 2013a; 2013b; 2013c) e Mayr \& Almada (2014).
} 
theorems, abbreviated as $\left.\mathrm{gT}^{\prime} \mathrm{s}\right)$ taking as reference isolated musical parameters (basically, intervallic or rhythmic contours), abstracted from the axiom. The intervallic/melodic and rhythmic gT's (respectively classified as M-gT's and R$\mathrm{gT}^{\prime}$ s) are yielded in two independent separate streams, with the application of transformational operations (e.g., inversion, augmentation, etc.) at the respective referential forms. Figure 1 illustrates the principal processes in abstract/DV1 level, taking as example a simple axiom. ${ }^{7}$

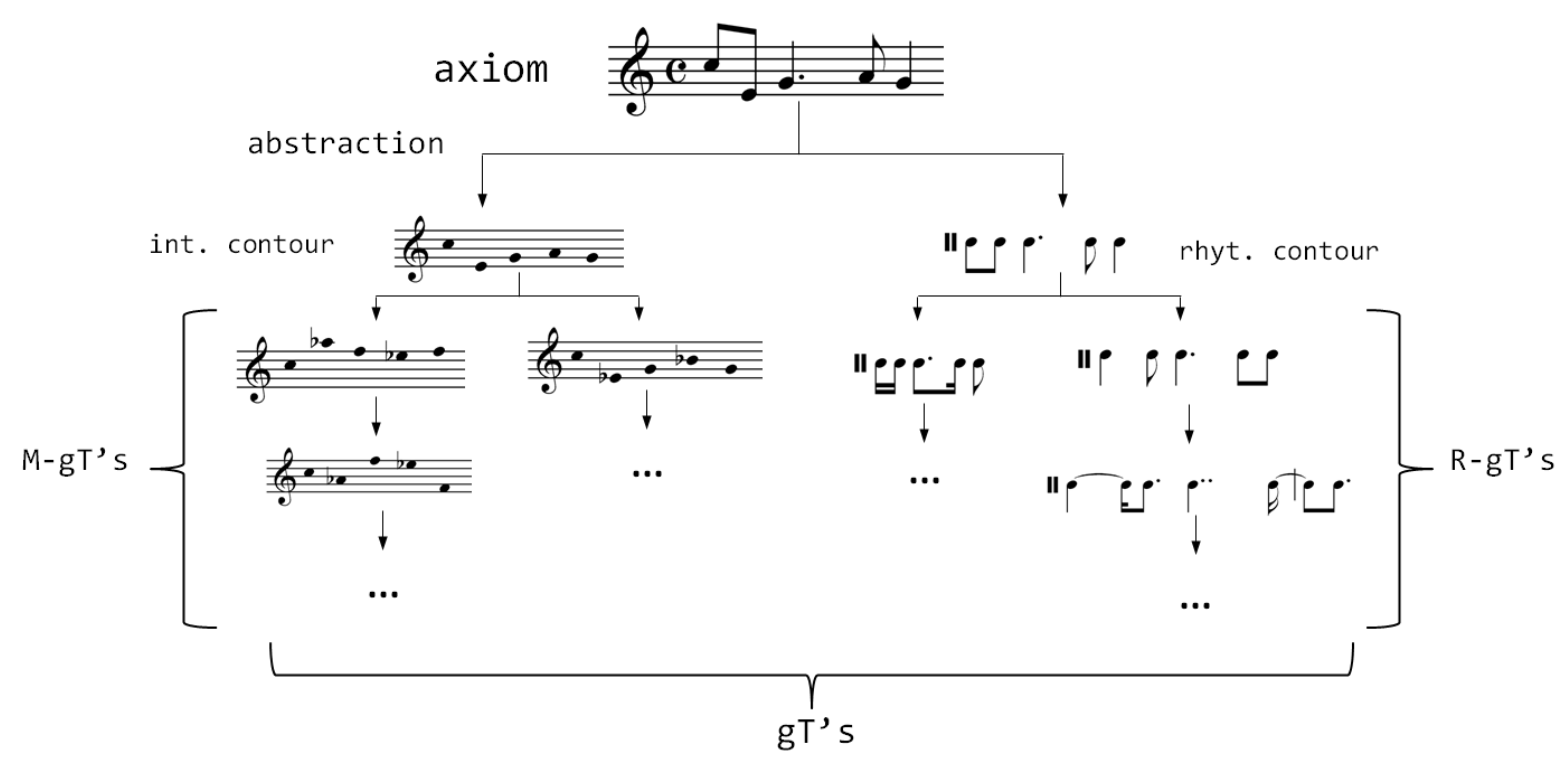

Figura 1: Basic schema of the production of gT's from a given axiom (DV1)

In the concrete level the production of variants (labeled as theorem-groups, thG's) is obtained taking as reference concrete (and generally more complex) musical structures, named axiomatic-groups (axG's). In this case, the transformational operations are directly applied at the referential forms, eliminating the intermediary step of abstraction (Figure 2).

\footnotetext{
${ }^{7}$ Evidently, there are presented in the example just a few of the possible derivative alternatives.
} 


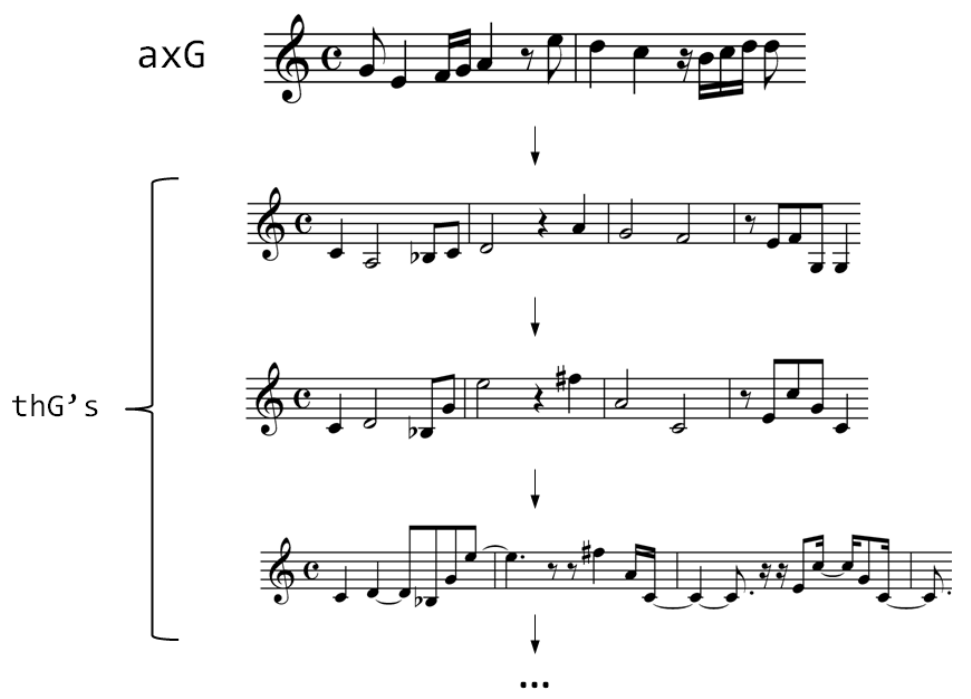

Figure 2: Basic schema of the production of thG's from a given axG (DV2)

The four modules are adjusted to this basic structure and are organized in a sequential and complementary order. Their functioning within the system can be briefly described as follows:

1. ax_gT (or "axiom produces geno-theorems"): this module is essentially responsible for DV1 procedures. Both referential forms (intervallic and rhythmic contours) are abstracted from the axiom, input as a monophonic midi file, becoming the basis for parallel production of gT's (M-gT's / R$\left.\mathrm{gT}^{\prime} \mathrm{s}\right)$ through application of transformational operations. ${ }^{8}$ This procedure can be replicated for an indefinite number of generations;

2. gT_pT ("geno-theorems produce pheno-theorems"): in this stage, M-gT's and R-gT's are crossed over in order to form concrete musical unities, named pheno-theorems ( $\mathrm{pT}^{\prime} \mathrm{s}$ ), which act as building blocks in the next step of the derivative process (as will be stated later, in this module some instructions for artificial selection are implemented);

3. pT_axG ("pheno-theorems produce axiomatic-groups"): the previously yielded $\mathrm{pT}^{\prime}$ 's are here concatenated (according to some user's decisions, as transpositions, metrical displacement, etc.) to form more complex structures, the axG's (in a similar manner as motives are joined for the construction of a theme);

\footnotetext{
${ }^{8}$ Each gT produced is associated to an index - the coefficient of similarity (Cs) - which ultimately measures the "parenthood" degree between a variant and the referential form. Special algorithms were developed during the research for the calculation of Cs (considering rhythmic or intervallic domains), returning a real number between 0 (total contrast) up to 1 (identity). For more detailed information about this issue, see Almada (2013d).
} 
4. axG_thG ("axiomatic-groups produce theorem-groups"): this last stage corresponds to the concrete phase of derivation (DV2), illustrated in Figure 2.

Figure 3 summarizes the complete functioning of $\mathrm{gM}$, considering the interaction of its four modules. ${ }^{9}$

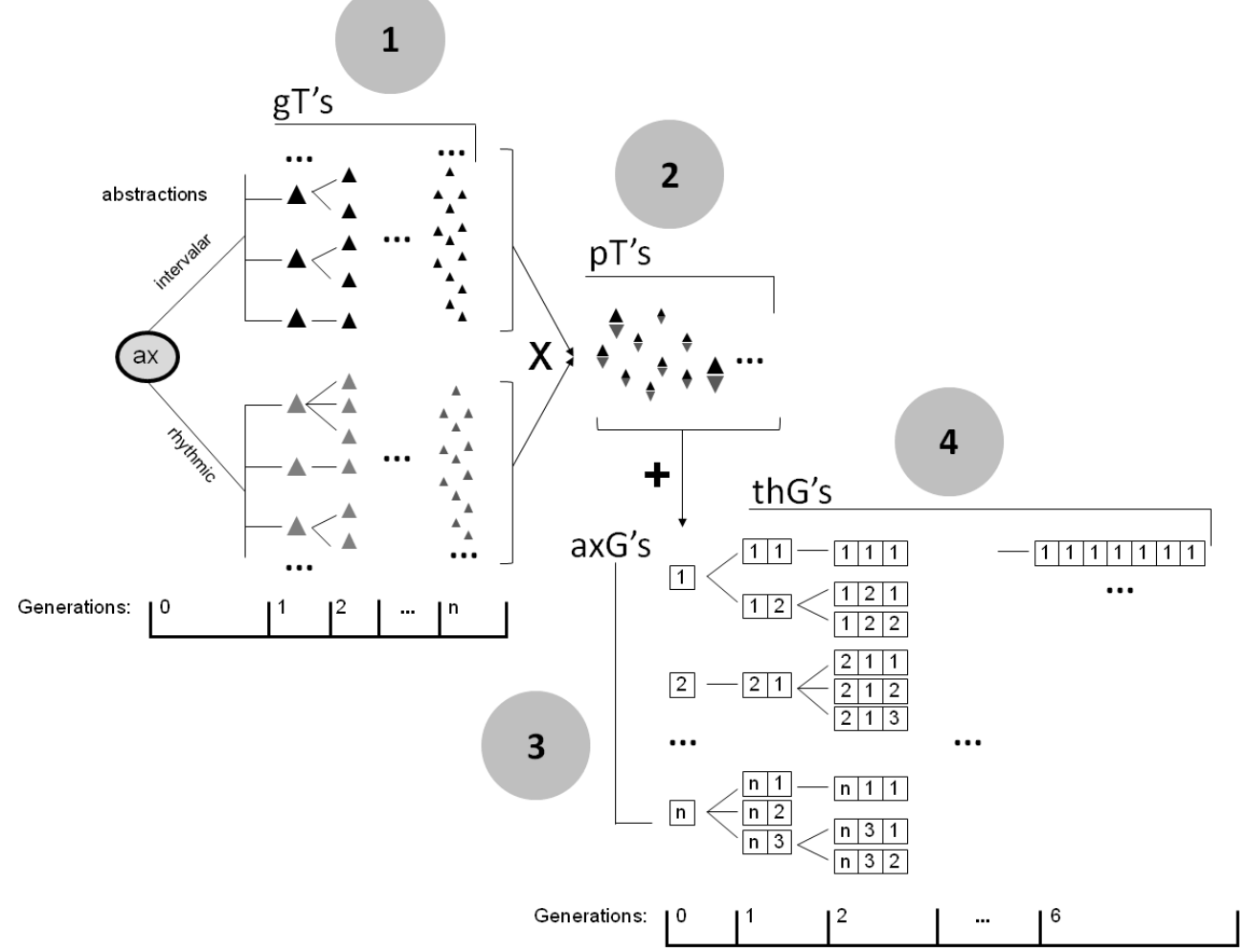

Figure 3: Basic schema of gM functioning and its four modules

\section{4 - Artificial selection applied to musical variation}

The first chapter of Charles Darwin's The origin of the species ${ }^{10}$ - one of the most important books ever written - is entitled "Variation under domestication" (Darwin 1872, p. 20-49), an introduction for the core of his revolutionary thesis: the natural selection, which ultimately models the development of life. In the course of the chapter, Darwin discusses a particular and considerably limited aspect of formation of new species and variations, namely, the artificial selection. The principal distinction between natural and artificial selections is that, in the

\footnotetext{
${ }^{9}$ For a more detailed description of gM's four modules, see Almada (2015b).

10 The complete title is: The origin of species by means of natural selection or the preservation of favoured races in the struggle for life.
} 
latter, the process is oriented by some clear (human) intention or planning. ${ }^{11}$ In this case, the pressure for selection of the fittest results (that becomes the basis for further reproduction) is highly more directed and faster than that occurs in the natural alternative, which depends on random mutations and is generally measured in tens or hundreds of thousands (or even millions) of years. Darwin illustrates artificial selection procedures with the profusion of dogs and pigeons races obtained during just a few centuries. Other cases can be observed in agriculture and in the creation of animals destined for food, like cattle, chickens, etc. Planning to increase the weight and size of his/her rabbits, for instance, a farmer will select from a given breed the fatter and bigger individuals for reproduction, to form a new generation. The process is then over and over repeated, leading to the production of new fatter and bigger rabbits variations, according to the initial intention. ${ }^{12}$

From this came naturally the idea to adapt the concept of artificial selection to the gM structure, not only to provide a proper control of the population of variants (an obvious and immediate objective), but also to direct the "aspect" of the desired forms according to the user's particular orientations. In other words, it was necessary to establish strategies able to maintain wellformed results for further development and, consequently, suppress those ones considered not suitable for the intended purposes. The next section describes the implementation of artificial selection in $\mathrm{gM}$, considering two procedures: (1) through a group of fitness functions (inserted in $\mathbf{g T} \mathbf{T} \mathbf{p} \mathbf{T}$ ) and (2) through choice based on phenotypic results (in axG_thG).

\section{5 - Strategies for artificial selection in gM}

A new version of the second module (gT_pT) was recently elaborated with the aim of allowing the application of fitness functions to previously formed pheno-theorems. In the initial stage seven functions were created, subdivided into two basic groups, aiming at either suppression of undesirable results or

${ }^{11}$ Even though, as Darwin comments in the same chapter (Darwin 1872, p. 41-46), eventually there is the possibility of occurrence of cases of "unconscious selection", that is, developments that are not so methodically controlled.

${ }^{12}$ Arguing against the common notion that there would exist a kind of reaction from the species to be changed by artificial selection, Richard Dawkins (2000, p. 305-306) affirms that "we [i.e., the selectors] do not fail when we try to shape evolution by selective breeding animals and plants in captivity, nor do we experience a period of initial difficulty. Animal and plant species are usually immediately amenable to selective breeding, and breeders detect no evidence of any intrinsic, anti-evolution forces. If anything, selective breeders experience difficulties after a number of generations of successful selective breeding. This is because after some generations of selective breeding the available genetic variation runs out, and we have to wait for new mutations." 
delimitation of some musical aspects. The first group contains three functions, applied to eliminate: (1) redundant $\mathrm{pT}^{\prime} \mathrm{s}$; (2) $\mathrm{pT}^{\prime}$ s that initiate and end with the same note (since this causes a strong closure effect, frequently unsuitable for some constructive finalities); (3) pT's with melodic lines presenting contiguous leaps that suggest broken chords referred to major, minor or diminished triads. ${ }^{13}$

There are four delimitation functions considering the following aspects: (4) melodic range: in this case the user chooses the highest and lowest note allowed for the $\mathrm{pT}^{\prime}$ 's (avoiding, thus, results with extremely high and/or low points); (5) maximal internal duration: the user determines the maximal duration allowed, to avoid eventual discrepancies; (6) maximal extension: in this case the user establish a limit for the $\mathrm{pT}^{\prime}$ 's total extension; (7) delimitation of Cs range, avoiding results that diverge sharply from the basic form (for example, Cs lower than 0.10) or conversely, those ones almost identical to it (e.g., Cs greater than 0.95). As an illustration of this implemented strategy, Figure 4 presents some possibilities of hypothetical ill-formed $\mathrm{pT}^{\prime}$ 's, properly eliminated from the system by application of fitness functions of numbers 2 to 6 .

Function / Conditions:

(2) Supression of pT's which initiate and end with the same note

(3) Supression of $\mathrm{pT}^{\prime} \mathrm{s}$ wich present tonal connotations

(4) Range delimitation (choosen limits: $A_{2} / C_{5}$ )

(5) Internal duration delimitation (choosen limit: half-note)

(6) Extension delimitation (choosen limit: four beats)
Examples:

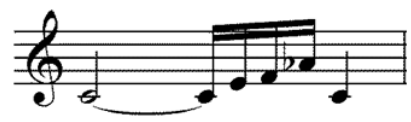

B (enharmonically)
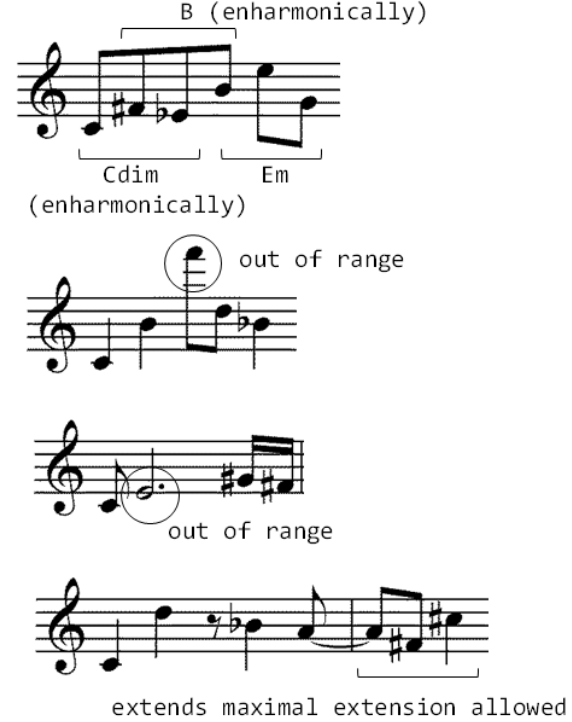

Figure 4: Some hypothetical ill-formed $\mathrm{pT}^{\prime}$ 's eliminated through application of the fitness functions 2 to 6 in $\mathbf{g T}$ T_p

13 As with the previous function, this constraint was established for situations where the user/composer intends to avoid any connotations to tonal ambiances in the selected $\mathrm{pT}^{\prime} \mathrm{s}$. Evidently, there will be cases when the opposite strategy must be adopted, in other words, with selection (and not suppression) of tonal-like forms. The implementation of new functions considering this alternative is planned for the next steps of the research. 
The new version of $\mathbf{g T}$ T_p $\mathbf{T}$ module also provides a sort of report of the performed selection process, presented in a graphic format. It plots the successive reductions of the initial breed of formed $\mathrm{pT}^{\prime}$ 's which are resulted from the application of the fitness functions. As a hypothetical example (Fig.5), taking a given basic set of $3819 \mathrm{pT}^{\prime}$ s, originated from the recombination of $67 \mathrm{M}-\mathrm{gT}^{\prime} \mathrm{s}$ and 57 R-gT's. ${ }^{14}$ The search for eventual redundancies (function 1) reduces this amount to 3025 individuals (in other words, the program has detected 794 copies of some $\mathrm{pT}^{\prime} \mathrm{s}$ ). The suppression of tonal references, by application of functions 2 and 3, results in further reductions, respectively, to 2090 and 1485. In the delimitation-functions' group, the following parameters were determined: melodic range - $\mathrm{E}_{2}$ to $\mathrm{D}_{5}$ (function 4); maximal internal duration - half-note (function 5); maximal extension - one 4/4 measure (function 6) and Cs limits from .6 to .9 (function 7 ). The application of these four functions provides the following decreasing sequence of selected pT's: 825, 780, 705 and 649. The final number corresponds to approximately $17 \%$ of the initial amount, representing an expressive reduction.

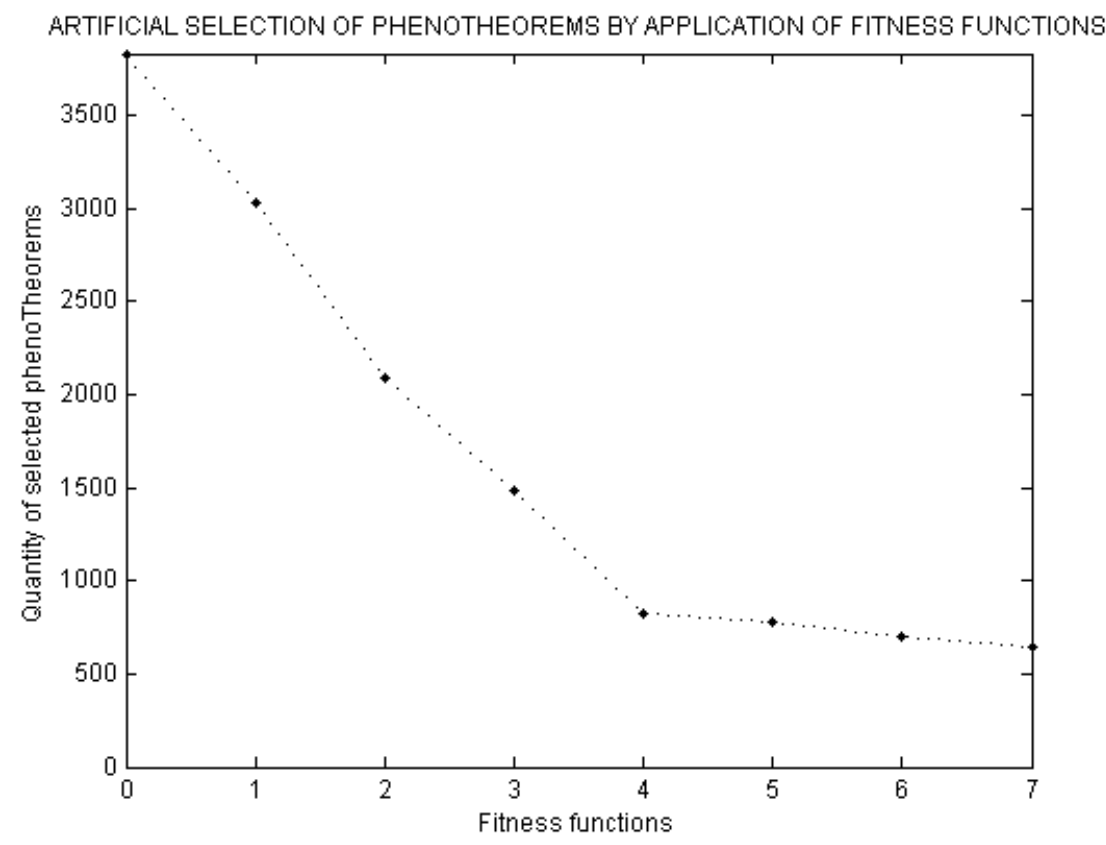

Figure 5: Graph of $\mathrm{pT}^{\prime} \mathrm{s}^{\prime}$ artificial selection by application of fitness function to a hypothetical case

${ }^{14}$ As above stated, $\mathrm{pT}^{\prime} \mathrm{s}$ are formed by crossing-over of previously produced abstracted forms, M-gT's and R-gT's, that is, from their product. Therefore, 67 M-gT's x 57 R-gT's = 3819 pT's. 


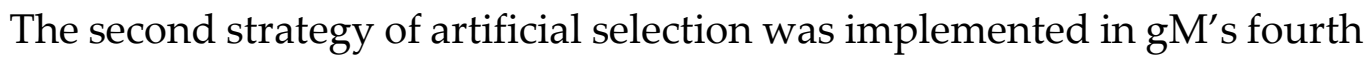
module (axG_thG), not being properly associated to any fitness function. Rather, the procedure, very similar to that one employed in animals and plants creation (Dawkins 2000, p. 70), is based on selection of results through examination of their phenotypic characteristics. As defined by Dawkins, the term "phenotype" is related to "the manifested attributes of an organism, the joint product of its genes and their environment during ontogeny. A gene may be said to have phenotype expression in, say, eye color." (Dawkins 2000, p. 299) In other words, a selector uses basically his/her senses (especially the vision) to choose the suitable forms that will be kept for reproduction and, consequently, the intended improvement of a lineage. In the present context, the user/composer combines vision to auditory capacity for the selection process, since the phenotypic attributes in this case correspond to musical characteristics (rhythm configuration, melodic contour, implied harmony, etc.).

Actually, the selective process performed in axG_thG is very simple: after the production of a given theorem-group (thG) through some DV2 procedure (that is, the application of a transformational operation at a referential form - an axG or a thG of the precedent generation), its musical translation (in a MIDI format) is automatically provided and temporarily preserved by the program in order to allow the user to adequately examine its musical structure. If its "phenotypic" qualities correspond to the user's constructive intentions (whatever they are), it may then be selected, being incorporated to the system and becoming a potential new "parent" for further generations. In the opposite case, the provisory variant is simply discarded and the user may make a new attempt (applying another operation to the same referential form, for example). Therefore, this selective (and somewhat trial-and-error) strategy, as those adopted by the farmers, intends basically to improve the lineages, by keeping in the system only the forms that fit some pre-determined parameters (conversely, eliminating those ones that are someway not suitable for the user's constructive purposes).

\section{6 - Conclusions}

Considering the basic purpose that motivated the principle of Darwinian artificial selection adaptation to the production of musical variants, namely, the population control, the implementation of both strategies here described in the gM's structure can be considered plainly successful. The same can certainly be said about its secondary or consequent purpose: to provide an adequate means for, so to speak, conduct (or orient) the successive breeding of variants according to pre-established musical intentions. In this sense, the mechanisms created allow the maintenance of the individuals that can contribute for the reinforcement of 
these intentions (providing coherence to the system), opening, at same time, lines of development (variety) of the basic ideas that can be adjusted to the compositional planning.

It is interesting to note that the needs of the both strategies are firmly associated to the basic characteristics of the respective modules in which they were implemented. In the case of $\mathbf{g T} \mathbf{T} \mathbf{p T}$, the final stage of DV1 processes, the employment of fitness functions seems an adequate means for picking up just the desirable results among a (usually) large amount of forms, acting as a kind of basic filter. Considering that the $\mathrm{pT}^{\prime} \mathrm{s}$ in the system have the essential function of building blocks for the creation of more complex structures (asides be formed in large quantities), it would be an impracticable task to intend to select them by their phenotypic qualities. Just the opposite can be considered in the case of module axG_thG. Since DV2 yields a variant form at each step, it can be treated as an individual final product with "idiosyncratic" musical qualities that demand to the selector an individual and careful examination through his/her auditory and visual senses. Considering this, the employment of fixed fitness functions seems innocuous, since it would be also impracticable to try covering all the possible alternatives.

Evidently, the implementation of these means corresponds to an initial stage, requiring further improvement, as for example to expand the group of fitness functions or to, someway, create auxiliary tools for the phenotypic examination of thG's, decreasing the degree of subjectivity in the selective process that exists in the current version of the fourth module.

A very interesting aspect highlighted in the present paper is the gradual increase of proximity between the research in which is inserted and the field of Biology, especially considering the areas of genetics and evolution. It can be observed not only in the more obvious questions of concepts and terminology, but in some more deep, structural aspects of the study, which reveals the fascinating affinities existent between the development of live forms and the musical variation. These have motivated new ramifications in the research, like in the present case. ${ }^{15}$ In a sense, the organicist origins of the Schoenbergian concepts of Grundgestalt and developing variation (the very base of the research) are still kept alive.

\footnotetext{
${ }^{15}$ In this aspect, see Almada (2015a) which proposes an adaptation of the principles of Darwin's theory to the creation of evolutionary lineages of variants from a basic thematic idea.
} 


\section{References}

1. Almada, Carlos de Lemos. 2015a. Evolution in Musical Contexts: The Software DARWIN. Anais do XXV Encontro Anual da Anppom. Vitória: UFES.

2. 2015b. Genetic algorithms based on the principles of

Grundgestalt and developing variation. In: Proceedings of the $3^{\text {rd }}$ Biennial Conference on Mathematics and Computation in Music, 2015. Londres: Queen Mary University.

3. 2013a. Novas perspectivas para a análise derivativa. Revista do Conservatório de Música da UFPel, Pelotas, n.6, p. 164-206.

4 . 2013b. O Sistema-Gr de composição musical baseada nos princípios de variação progressiva e Grundgestalt. Música e Linguagem, Vitória, vol. 2, no 1 , p.1-16.

5. 2013c. Simbologia e hereditariedade na formação de uma Grundgestalt: a primeira das Quatro Canções Op.2 de Berg. Per Musi - Revista Acadêmica de Música, Belo Horizonte, n.27, p. 75-88.

6. 2013d. Comparação de contornos intervalares como parâmetro de medição de similaridade. Anais do III Encontro de Teoria e Análise Musical. São Paulo: ECA-USP, p. 205-214.

7. 2012. Um modelo analítico para variação progressiva e Grundgestalt. Anais do XXII Encontro Anual da Anppom. João Pessoa: UFPB, 12p.

8. 2011a. Derivação temática a partir da Grundgestalt da Sonata para Piano op.1, de Alban Berg. Anais do III Encontro de Teoria e Análise Musical. São Paulo: UNESP-USP-UNICAMP, cd-rom, 11p.

9. Burts, Devon. 2004. An application of the grundgestalt concept to the First and Second Sonatas for Clarinet and Piano, Op. 120, no. 1 E no. 2, by Johannes Brahms. Tampa, Dissertation (Mastership in Music), 66f. University of South Florida.

10. Carpenter, Patricia. 1983. Grundgestalt as tonal function. Music Theory Spectrum, vol. 5, p. 15-38.

11. Colleen, Marie C. 2009. The lessons of Arnold Schoenberg in teaching: The Musikalische Gedanke. PhD Dissertation, University of North Texas. 
12. Dahlhaus, Carl. What is 'developing variation'? In: Schoenberg and the New Music (Derrik Puffett \& Alfred Clayton, trad). Cambridge: Cambridge University Press.

13. Darwin, Charles. The origins of the species (6th Ed., 1872). Available in:

https://www.andrew.cmu.edu/user/jksadegh/A\%20Good\%20Atheist\%20Secular ist\%20Skeptical\%20Book\%20Collection/Charles\%20Darwin\%20\%20The\%20Origin\%20of\%20Species\%20-\%206th\%20Edition.pdf

14. Dawkins, Richard. 2000. The blind watchmaker. $3^{\text {rd }}$ edition. London: Penguin Books

15. Dawkins, Richard. 2006. The selfish gene. $3^{\text {rd }}$ edition. Oxford: Oxford University Press.

16. Dudeque, Norton. 2005. Music theory and analysis in the writings of Arnold Schoenberg (1874-1951). Aldershot: Ashgate Publishings.

17. Freitas, Sérgio. 2012. Da música como criatura viva: repercussões do organicismo na teoria contemporânea. Revista Científica / FAP, Curitiba, v.9, janjun, p.64-82.

18. Frisch, Walter. 1984. Brahms and the principle of developing variation. Los Angeles: University of California Press.

19. 1997. The refractory masterpiece: toward an interpretation of Schoenberg's Chamber Symphony, op. 9. In: BRAND, Juliane \& HAILEY, Christopher (Eds.). Constructive dissonance: Arnold Schoenberg and the transformations of twentieth-century culture, p.87-99 Berkeley: University of California.

20. Haimo, Ethan. 1997. Developing variation and Schoenberg's serial music. Musical Analysis, v. 16, n. 3, p. 349-365.

21. Mayr, Desirée \& Almada, Carlos de Lemos. 2014. Uma aplicação da análise derivativa na música romântica brasileira: $O$ primeiro movimento da Sonata para Violino e Piano Op.14, de Leopoldo Miguéz. Anais do I Congresso da Associação Brasileira de Teoria e Análise Musical. Salvador: UFBA, p.19-37.

22. Meyer, Leonard. 1989. Style and music. Chicago: The University of Chicago Press. 
23. Pye, Richard. 2000. 'Asking about the Inside': Schoenberg's 'Idea' in the Music of Roy Harris and William Schuman. Music Analysis, v. 19, n. 1, p. 69-98.

24. Schoenberg, Arnold. 1984. Style and idea: selected writings of Arnold Schoenberg. (Leonard Stein, ed.). Londres: Faber \& Faber.

25. 1988. Modelos para estudiantes de composicion. (Leonard Stein, ed.; Violeta H. de Gainza, trad.). Buenos Aires: Ricordi.

26. 1990. Fundamentals of musical composition. (Gerald Strang, ed.) Londres: Faber \& Faber.

27. 1994. Coherence, counterpoint, instrumentation in form. (Severine Neff, ed.; Severine Neff \& Charlotte Cross, trad.). Lincoln: University of Nebraska Press.

28. . 2006. The musical idea and the logic, technique, and art of its presentation. (Patricia Carpenter \& Severine Neff, trad. e ed.). Bloomington: Indiana University Press. 